\title{
ROBEKAN PERINEUM PADA PERSALINAN VAGINAL DI BIDAN PRAKTEK SWASTA (BPS) DAERAH ISTIMEWA YOGYAKARTA INDONESIA TAHUN 2014-2016
}

\author{
Nuring Pangastuti ${ }^{1}$
}

\begin{abstract}
Background: Vaginal delivery is the most preffered mode of delivery by all women, and the birth attendants. The vaginal delivery assistance was conducted by various health professionals such as midwives, physicians, and obstetricians. Various complaints of pelvic floor dysfunction and complaints related to the perineum as a result of vaginal perineal laceration during childbirth can affect the quality of life of a woman.

Objective: To identify and conduct an analysis of maternal factors (maternal age, parity, gestational age), fetal factor (birth weight), and the labor factor (duration of $2^{\text {nd }}$ stage of labor), with the occurrence of perineal rupture in vaginal delivery at the 5 Midwife's Private Clinic (MPC), Yogyakarta, Indonesia.

Method: Retrospective medical record searching, from January 2014 until December 2016.

Result and Discussion: There were 1595 obtained samples of data that met the criteria for inclusion and exclusion. Number of perineal laceration reached 1201 (75.3\%), with $1.9 \%$ of them are grade 3. Perineal rupture occurred in $80.55 \%$ of vaginal deliveries at young age, $69.14 \%$ in more than 35 years old women, and $85.05 \%$ primiparas. There was significant negative correlation $(0.186)$ between parity and perineal rupture $(p=0.000)$. The less the parity, the higher the incidence of perineal rupture $(p=0.002)$. There was significant correlation between baby's weight less than 2500 gram and perineal rupture but not for the baby's weight more than 4000grams ( $p=0.304)$. The correlation was positive which meant that the heavier the baby's weight the higher the incidence of perineal rupture. There was significant positive correlation $(p=0,018)$ for the duration of 2 nd stage of labor between 30-60 minutes and perineal rupture $(0.061)$. The correlation was positive as well $(0.092)$ for the duration of 2 nd stage of labor more than 60 minutes and perineal rupture( $p=0.002)$. The longer the duration of the 2 nd stage of labor the higher the incidence of perineal rupture.

Conclusion: There was significant relationship between parity, and duration of the $2^{\text {nd }}$ stage of labor and perineal rupture in vaginal delivery.
\end{abstract}

Keywords: perineal rupture, vaginal delivery, parity, duration of the $2^{\text {nd }}$ stage of labor

\begin{abstract}
ABSTRAK
Latar Belakang: Persalinan vaginal merupakan cara persalinan yang paling banyak dipilih oleh semua perempuan, dan tenaga kesehatan selaku penolong persalinan. Berbagai keluhan disfungsi dasar panggul maupun keluhan terkait perineum sebagai akibat robekan perineum saat persalinan vaginal dapat mempengaruhi kualitas kehidupan perempuan.

Tujuan: Mengetahui dan melakukan analisis terhadap faktor ibu (usia ibu, paritas, usia kehamilan), faktor janin (berat bayi lahir), dan faktor persalinan (lama kala II), dengan terjadinya robekan perineum pada persalinan vaginal di 5 Bidan Praktek Swasta (BPS) Daerah Istimewa Yogyakarta Indonesia.
\end{abstract}

${ }^{1}$ Departemen Obstetri Ginekologi Fakultas Kedokteran Universitas Gadjah Mada RSUP Dr Sardjito Yogyakarta 
Metode: Penelusuran data rekam medik retrospektif, Januari 2014 - Desember 2016, di 5 BPS Daerah Istimewa Yogyakarta Indonesia.

Hasil dan Pembahasan: Didapatkan 1595 sampel data yang memenuhi kriteria inklusi dan eksklusi. Jumlah robekan perineum mencapai 1201 (75,3\%), dan 1,9\% diantaranya adalah derajat 3 . Robekan perineum terjadi pada $80,55 \%$ usia muda, $69,14 \%$ usia lebih dari 35 tahun, serta $85,05 \%$ primipara. Terdapat kemaknaan pada hubungan paritas dengan robekan perineum (nilai $p=0,000$ ), dengan korelasi negatif $(0,186)$. Koefisien korelasi negatif menunjukkan bila paritas makin kecil, maka kejadian robekan perineum akan meningkat.

Terdapat kemaknaan pada hubungan antara berat badan bayi lahir kurang dari 2500 gram dengan robekan perineum $(p=0,002)$, namun $p=0,304$ untuk bayi besar (berat bayi lahir lebih atau sama dengan 4000 gram). Korelasi positif $(0,027)$ menunjukkan pada persalinan dengan berat bayi lahir makin besar, risiko robekan perineum meningkat.

Hubungan lama kala II dengan robekan perineum juga menunjukkan kemaknaan dengan nilai $p=0,018$ untuk lama kala II 30-60 menit, dan p=0,002 untuk lama kala II lebih dari 60 menit. Didapatkan korelasi positif $(0,061$ dan 0,092$)$ pada kedua kemaknaan tersebut. Bila lama kala II memanjang, maka kejadian robekan perineum akan meningkat.

Kesimpulan: Terdapat hubungan bermakna antara paritas (faktor ibu), berat bayi lahir (faktor janin), dan lama kala II (faktor persalinan), dengan terjadinya robekan perineum pada persalinan vaginal, yang berkorelasi positif.

Kata kunci: robekan perineum, persalinan vaginal, paritas, lama kala II persalinan

\section{PENDAHULUAN}

Persalinan normal atau spontan vaginal merupakan cara persalinan yang umumnya senantiasa diharapkan oleh semua perempuan. Pertolongan persalinan vaginal dilakukan oleh banyak tenaga kesehatan seperti bidan, dokter, maupun dokter spesialis obstetri ginekologi. Pada persalinan normal ibu dan bayi dalam kondisi sehat, ibu dapat segera pulih dan dapat melakukan aktifitas kesehariannya kembali. ${ }^{1}$ Pertolongan persalinan vaginal mengikuti kaidah Asuhan Persalinan Normal (APN) yang merupakan standar pertolongan persalinan vaginal di seluruh Indonesia. Dengan APN diharapkan persalinan berlangsung sealamiah mungkin dan aman. ${ }^{2,3}$

Salah satu kondisi yang seringkali menyertai proses persalinan adalah robekan perineum. Insidensi robekan perineum pada persalinan vaginal mencapai $85 \%$. Robekan derajat berat bahkan mencapai sfingter anal atau robekan perineum total memiliki insidensi yang cukup luas variasinya, berkisar 6-20\%. Mengikuti kaidah pertolongan yang benar sekalipun, termasuk APN, seringkali robekan perineum tidak dapat dihindari sebagai konsekuensi proses persalinan itu sendiri. ${ }^{2,4-6}$

Robekan perineum pada persalinan vaginal, memberikan defek anatomi maupun fungsi pada perempuan. Sekalipun telah dilakukan perbaikan atau penjahitan robekan, tetap saja efek ini dapat mempengaruhi kualitas kehidupan perempuan yang bersangkutan. Keadaan ini antara lain juga memberi kontribusi pada munculnya keluhan disfungsi dasar panggul di kemudian hari. Pada persalinan yang disertai robekan perineum tidak teratur atau luas, umumnya berkorelasi dengan proses penjahitan yang rumit, keluhan nyeri perineum pasca salin maupun disfungsi dasar panggul yang lebih berat. $^{7}$ 
Dari data tahun 2015 didapatkan bahwa cakupan persalinan oleh tenaga kesehatan di DIY mencapai 99,95\% dan menjadi penyumbang terbesar persentase keseluruhan cakupan di tingkat nasional Indonesia (85,58\%). Seluruh kabupaten daerah tingkat II dan kotamadya di DIY memiliki angka cakupan lebih dari 99\%. Persalinan penduduk DIY umumnya juga telah dilakukan di berbagai fasilitas kesehatan yang ada. Cakupan pertolongan persalinan yang ditolong tenaga kesehatan di fasilitas kesehatan di DIY mencapai angka 99,81\% (angka nasional Indonesia adalah 78,80\%). ${ }^{8}$

Bidan merupakan profesi tenaga kesehatan yang khusus bekerja di ranah pemeliharaan ibu hamil sampai dengan pertolongan persalinan, merawat ibu maupun bayinya. Meski cakupan pertolongan persalinan oleh tenaga kesehatan di DIY tinggi, angka ini merupakan hasil rangkuman berbagai profesi yang bekerja di fasilitas kesehatan tersebut. Rasio bidan per 100.000 penduduk DIY adalah 26,55. Target nasional yaitu 100 bidan per 100.000 penduduk Indonesia. Untuk tingkat nasional, rasio bidan per 100.000 penduduk Indonesia adalah 43,74. Bila dibandingkan di area regional Jawa Bali maka DIY berada di urutan ke 5 dari 7 daerah tingkat I di wilayah tersebut. ${ }^{8}$

Rasio Pusat Kesehatan Masyarakat (Puskesmas) per 30.000 penduduk di DIY sudah mencapai 99\%, meskipun penyebarannya belum merata. Persentase Puskesmas di DIY yang belum memenuhi standar jumlah bidan mencapai $60,33 \%$. Tenaga kesehatan lain sebagai penolong persalinan yang bekerja di Puskesmas sebagai lini pertama atau fasilitas kesehatan primer lainnya adalah dokter umum. Rasio dokter umum per 100.000 penduduk di Indonesia tahun 2015 adalah 16,06, dan DIY memiliki rasio 28,24 per 100.000 penduduk (nomor urut ke 4 di seluruh Indonesia). Target nasional adalah 40 dokter umum per 100.000 penduduk. Untuk regional
Jawa Bali, DIY menduduki peringkat pertama rasio tersebut. Dibandingkan dengan standar, seluruh Puskesmas di DIY telah memenuhi standar kecukupan sumber daya dokter umum kecuali di wilayah daerah tingkat II kabupaten kulonprogo, masih terdapat $4,76 \%$ belum memenuhi standar. ${ }^{8}$

Mengingat kekhususan profesi dan angka kecukupan yang ada, menjadi penting untuk berupaya mengetahui gambaran pertolongan persalinan vaginal yang dilakukan oleh bidan di berbagai lini pertama fasilitas kesehatan termasuk rumah bersalin maupun sebagai Bidan Praktek Swasta (BPS) mandiri. Penelitian ini bertujuan mengetahui dan melakukan analisis tentang terjadinya robekan perineum pada persalinan vaginal di BPS. Analisis meliputi hubungan faktor ibu (usia ibu, paritas, usia kehamilan), faktor janin (berat bayi lahir), dan faktor persalinan (lama kala II), dengan robekan perineum. Pengetahuan ini diharapkan dapat digunakan pada upaya meminimalkan risiko terjadinya robekan perineum pada persalinan vaginal.

\section{METODE}

Tulisan ini merupakan suatu laporan penelitian deskripsi analitik. Populasi sampel penelitian dikumpulkan dari seluruh data rekam medik pasien persalinan vaginal di Bidan Praktek Swasta (BPS) Daerah Istimewa Yogyakarta Indonesia. Masing-masing kabupaten/kotamadya yaitu Kabupaten Sleman, Bantul, Kulonprogo, Gunungkidul, dan Kotamadya Yogyakarta, diwakili oleh satu BPS. Penelitian dilakukan di klinik bersalin BPS yang bersangkutan, mulai bulan Februari tahun 2016 sampai dengan bulan Januari tahun 2017.

Kriteria inklusi pada penelitian ini adalah data rekam medik persalinan spontan vaginal, tanpa maupun dengan robekan perineum, tahun 2014, 2015, dan 2016. Kriteria eksklusi adalah data rekam medik pasien yang dirujuk saat proses 
persalinan, maupun data yang tidak lengkap. Variabel bebas meliputi data paritas, berat badan lahir bayi, serta lama kala II. Variabel tergantung berupa data perineum, yaitu dibagi menjadi data perineum utuh, episiotomi, perineum robek, serta derajat robekan perineum. Yang masuk dalam variabel luar adalah data usia ibu serta usia kehamilan.

Data diolah menggunakan aplikasi SPSS. Analisis univariat dilakukan untuk mengetahui karakteristik subjek penelitian. Analisis bivariat merupakan analisis nonparametrik dengan uji korelasi Spearman Rank untuk mengetahui adanya hubungan antara variabel bebas dan terikat dikarenakan data penelitian tidak terdistribusi normal. Untuk mengetahui hubungan antara paritas, berat badan lahir bayi, dan lama kala dua persalinan terhadap terjadinya robekan perineum maka dilakukan analisis regresi logistik.

\section{HASIL DAN PEMBAHASAN}

Pengambilan data retrospektif rekam medis dari tahun 2014 sampai dengan tahun 2016 menghasilkan 1595 sampel data yang memenuhi kriteria inklusi dan eksklusi. Subjek termuda berusia 14 tahun, sedangkan usia tertua yaitu 47 tahun. Rata-rata usia ibu yang melakukan persalinan vaginal di BPS Provinsi Daerah Istimewa Yogyakarta adalah 27,69 $\pm 5,810$ tahun. Berat terendah bayi yang dilahirkan adalah 1300 gram, yang terberat 4500 gram, sehingga rata-rata berat badan bayi lahir adalah 3072,23 $\pm 414,377$ gram.

Paritas subjek dikelompokkan menjadi beberapa kelompok. Primipara untuk subjek dengan riwayat paritas satu kali, multipara untuk subjek dengan riwayat paritas 2-4 kali, grandemultipara untuk subjek dengan riwayat paritas 5-6 kali, sedangkan great grandemultipara untuk riwayat paritas $\geq 7$ kali. Paritas terbanyak adalah keseluruhan multipara (termasuk grandemultipara dan great grandemultipara), mencapai 953 atau 59,75\% dari seluruh sampel penelitian.

Usia kehamilan paling banyak adalah hamil aterm (37-40 minggu) sebesar 1460 (91,5\%). Usia kehamilan preterm (kurang dari 37 minggu) mencapai 3,2\%, sedangkan hamil lewat waktu (pada pengumpulan data ini adalah usia kehamilan lebih dari 40 minggu) sejumlah 5,3\%.

Berat bayi lahir umumnya adalah berat normal, yaitu dalam rentang 2500 gram sampai dengan 4000 gram. Persalinan dengan bayi besar sebanyak $2,6 \%$. Lama kala II umumnya berlangsung dalam waktu kurang dari 30 menit. Kala II yang berlangsung dalam waktu lebih dari 60 menit sejumlah $5,6 \%$.

Meskipun pertolongan persalinan telah dilakukan dengan baik dan benar, sebagian besar perempuan tetap mengalami trauma perineum saat persalinan dan memerlukan perbaikan perineum. Sebagian pasien bahkan mengalami robekan perineum derajat III sampai IV (robekan perineum derajat berat atau total). Penilaian derajat robekan perineum kadangkala bervariasi atau kurang tepat terkait faktor ketidaktahuan penolong persalinan maupun pasien itu sendiri. (4-6)

Dari seluruh subjek penelitian didapatkan 1201 (75,3\%) mengalami robekan perineum. Kejadian episiotomi sebanyak 35 sampel $(2,2 \%)$ telah ditambahkan dalam kelompok tersebut. 
Tabel 1. Karakteristik subjek penelitian

\begin{tabular}{lcc}
\hline \multicolumn{1}{l}{ Variabel } & $\begin{array}{c}\text { Frekuensi } \\
\mathbf{n}\end{array}$ & $\begin{array}{c}\text { Persentase } \\
\%\end{array}$ \\
\hline *Umur (tahun) & 108 & 6,8 \\
$<20$ & 1325 & 83,1 \\
$20-35$ & 162 & 10,2 \\
$>35$ & & \\
*Paritas & 642 & 40,3 \\
Primipara & 953 & 59,7 \\
Multipara & & \\
*Umur kehamilan (minggu) & 51 & 3,2 \\
Preterm & 1460 & 91,5 \\
Aterm & 84 & 5,3 \\
Lewat waktu & & \\
Berat Bayi Lahir (gram) & 100 & 6,3 \\
<2500 & 1454 & 91,2 \\
2500-3999 & 41 & 2,6 \\
$>4000$ & & \\
Lama Kala II (menit) & 1032 & 64,7 \\
$<30$ & 474 & 29,7 \\
30-60 & 89 & 5,6 \\
$>60$ & & 75,3 \\
Robekan perineum & 1201 & 24,7 \\
Ya & 394 & \\
Tidak & & \\
\hline
\end{tabular}

Uji normalitas variabel Kolmogorov-Smirnov digunakan untuk mengetahui distribusi data variabel penelitian. Dari data usia ibu, paritas, usia kehamilan, berat bayi lahir, dan lama kala II, didapatkan hasil signifikansi sebesar $p=0,000$ $(p<0,05)$. Data yang memiliki signifikansi di bawah 0,05 memiliki perbedaan bermakna dengan data normal baku, sehingga hasil tersebut dapat diartikan sebagai distribusi data yang tidak normal. Demikian pula bila uji dilakukan khusus pada data perineum yang robek saja, maka dapat ditampilkan bahwa distribusi data tidak normal.

Uji homogenitas bertujuan mengetahui apakah subjek yang diambil berasal dari suatu populasi dengan variansi sama. Kecuali data berat bayi lahir, data dasar lain yaitu usia ibu, paritas, usia kehamilan, berat lahir bayi, serta lama kala II, berdasarkan kondisi perineum keseluruhan, didapatkan signifikansi $p<0.05$. Pada kemaknaan yang diperoleh lebih kecil dari 0,05 maka berarti data-data usia ibu, paritas, usia kehamilan, dan lama kala II, tidak memiliki varian yang sama. Untuk kondisi robekan perineum, variansi berbeda didapatkan pada data-data usia ibu dan lama kala II, sedangkan data-data lain memiliki variansi yang sama.

Robekan perineum spontan mencapai angka $1166(73,1 \%)$, sementara episiotomi dilakukan pada 2,2\% subjek penelitian. Berdasarkan karakteristik seluruh subjek penelitian, robekan 
perineum paling banyak terjadi pada ibu berusia 20-35 tahun $(83,1 \%)$. Hal ini dapat dikarenakan jumlah subjek penelitian terbanyak berada di rentang usia tersebut, selain juga merupakan rentang usia reproduksi sehat. Persalinan vaginal pada usia muda yaitu kurang dari 20 tahun masih mencapai $6,8 \%$, dengan angka robekan perineum 5,45\% dari seluruh data, namun mencapai $80,55 \%$ dari kelompok persalinan usia muda tersebut. Persalinan vaginal pada usia lebih dari 35 tahun mencapai 10,2\%, dengan kejadian robekan perineum mencapai $7,02 \%$ dari seluruh subjek penelitian, atau $69,14 \%$ dari kelompok persalinan di usia tersebut.

Sebanyak 40,3\% adalah kasus robekan primipara, sedangkan $59,7 \%$ terjadi pada multipara, dengan jumlah subjek multipara yang lebih besar dari primipara. Namun demikian, bila kita melihat dalam kelompok primipara itu sendiri, maka robekan perineum terjadi pada $85,05 \%$ persalinan. Ini adalah angka yang cukup tinggi dari umumnya persentase robekan perineum yang diampaikan pada berbagai laporan penelitian. Hal ini dapat terjadi karena jaringan yang belum pernah teregang sebelumnya, mengakibatkan elastisitas kurang baik, dan mudah robek pada persalinan.

Hasil tersebut sesuai dengan banyak teori yang menyebutkan faktor risiko robekan perineum pada ibu antara lain adalah usia ibu terlalu muda atau terlalu tua, dan persalinan pertama. Hal lain yang menjadi faktor risiko ibu juga adalah perineum pendek (kurang dari $3 \mathrm{~cm}$ ), serta adanya riwayat robekan perineum pada persalinan terdahulu. ${ }^{1,5,9-11}$

Dari data usia kehamilan, karena distribusi data yang terbanyak adalah pada usia kehamilan aterm, dapat dimengerti bahwa jumlah robekan perineum terbanyak adalah berada di usia kehamilan tersebut. Pada penelitian ini yang dimasukkan dalam kelompok usia kehamilan aterm adalah di rentang usia 37-40 minggu. Usia kehamilan lewat waktu (lebih dari 40 minggu) merupakan salah satu faktor risiko robekan perineum. Dari keseluruhan data didapatkan kejadian robekan perineum pada usia kehamilan lewat waktu adalah 4,04\%, atau mencapai $76,19 \%$ dalam kelompok usia kehamilan lewat waktu itu sendiri.

Faktor risiko robekan perineum yang berasal dari janin meliputi bayi besar, malposisi atau malpresentasi, maupun kelainan letak. Robekan perineum banyak terjadi pada persalinan dengan berat bayi besar, atau lebih dari 4000 gram. ${ }^{1,5,9-11} \mathrm{Hal}$ ini terkait peregangan maksimal area perineum untuk mengakomodir terutama lingkar kepala dan bahu janin yang akan lahir. Data menunjukkan robekan perineum terbanyak terjadi di berat bayi lahir normal yaitu antara 2500-4000 gram (76\%). Dapat dicermati bahwa untuk persalinan dalam kelompok berat bayi lebih dari 4000 gram, meskipun robekan perineum hanya $2,13 \%$ dari keseluruhan subjek, namun di dalam kelompok berat bayi lahir lebih dari 4000 gram itu sendiri angka robekan perineum mencapai $82,92 \%$.

Proses persalinan baik presipitatus maupun partus lama, lama kala II, penggunaan alat bantu seperti vakum maupun forceps pada persalinan Kala II, ikut berperan pada terjadinya robekan perineum. Pada durasi lama kala II yang makin panjang, jaringan perineum menjadi oedem, rapuh, sehingga mudah robek. . $^{1,5,9-11}$

Subjek terbanyak adalah pada persalinan dengan lama kala II kurang dari 30 menit, robekan perineum mencapai $47,08 \%$ dari keseluruhan data, atau $78,48 \%$ dalam kelompok lama kala II tersebut. Pada pemanjangan durasi lama kala II lebih dari 60 menit, persentase meningkat mencapai $87,64 \%$.

Robekan perineum dapat terjadi spontan, maupun sebagai akibat dilakukannya episiotomi. Episiotomi rutin tidak disarankan dilakukan pada setiap pertolongan persalinan, karena tidak terbukti mampu mencegah terjadinya disfungsi 
dasar panggul, bila dibandingkan robekan spontan maupun tanpa robekan perineum. Demikian pula pengaruhnya pada janin tidak berbeda bermakna. Robekan perineum, baik spontan maupun episiotomi merupakan faktor yang mencederai perineum. Keadaan ini dapat berkontribusi pada terjadinya inkontinensia fekal, dispareunia, maupun keluhan disfungsi dasar panggul yang lain. Episiotomi mediana disebutkan berkaitan langsung dengan risiko terjadinya robekan perineum total, maupun keluhan inkontinensia fekal. ${ }^{7,12}$

Tabel 2. Karakteristik perineum

\begin{tabular}{lcc}
\hline \multicolumn{1}{c}{ Variabel } & $\begin{array}{c}\text { Frekuensi } \\
\mathrm{n}\end{array}$ & $\begin{array}{c}\text { Persentase } \\
\%\end{array}$ \\
\hline Robek derajat 1 & 221 & 13,9 \\
Robek derajat 2 & 914 & 57,3 \\
Robek derajat 3 & 31 & 1,9 \\
Episiotomi & 35 & 2,2 \\
Utuh & 394 & 24,7 \\
\hline
\end{tabular}

Derajat robekan perineum terbanyak pada hasil penelitian adalah robekan derajat 2 , yaitu robekan sampai dengan otot-otot perineum. Meskipun persentasenya jauh lebih kecil (1,9\%), robekan perineum derajat 3 masih terjadi. Dari data didapatkan bahwa robekan perineum tidak hanya terjadi pada primipara namun juga pada multipara, dengan berat bayi yang bervariasi. Tidak disebutkan derajat robekan secara lebih rinci, sehingga tidak diketahui sejauh mana keterlibatan otot sfingter ani eksterna maupun interna (derajat robekan 3a, 3b, atau 3c). Rincian robekan perineum derajat 3 diperlukan terkait penjahitan yang dilakukan, serta tata laksana lain yang mengikutinya.

Tabel 3. Hubungan faktor ibu, janin, persalinan, dengan robekan perineum

\begin{tabular}{|c|c|c|c|c|}
\hline \multirow{2}{*}{ Variabel } & \multicolumn{2}{|c|}{ Robekan perineum } & \multirow{2}{*}{$\mathrm{RR}(95 \% \mathrm{Cl})$} & \multirow{2}{*}{$\mathrm{p}$} \\
\hline & Ya (\%) & Tidak (\%) & & \\
\hline \multicolumn{5}{|l|}{ *Umur (tahun) } \\
\hline$<20$ & $1002(75,62)$ & $323(24,38)$ & I & \\
\hline $20-35$ & $87(80,55)$ & $21(19,45)$ & $1,065(0,966-1,174)$ & 0,248 \\
\hline$>35$ & $112(69,14)$ & $50(30,86)$ & $0,914(0,821-1,018)$ & 0,072 \\
\hline \multicolumn{5}{|l|}{ *Paritas } \\
\hline Primipara & $546(85,05)$ & $96(14,95$ & $1,237(1,173-1,306)$ & 0,000 \\
\hline Multipara & $655(68,73)$ & $298(31,27)$ & & \\
\hline \multicolumn{5}{|c|}{ *Umur kehamilan (minggu) } \\
\hline Preterm & $1104(75,62$ & $356(24,38)$ & 1 & \\
\hline Aterm & $33(64,71)$ & $18(35,29$ & $0,856(0,697-1,050)$ & 0,076 \\
\hline Lewat waktu & $64(76,19)$ & $20(23,81)$ & $1,008(0,891-1,140)$ & 0,905 \\
\hline \multicolumn{5}{|c|}{ Berat Bayi Lahir (gram) } \\
\hline$<2500$ & $1105(76,00)$ & $349(24,00)$ & 1 & \\
\hline 2500-3999 & $62(62,00)$ & $38(38,00)$ & $0,816(0,698-0,954)$ & 0,002 \\
\hline$>4000$ & $34(82,93)$ & $7(17,07)$ & $1,091(0,947-1,257)$ & 0,304 \\
\hline \multicolumn{5}{|c|}{ Lama Kala II (menit) } \\
\hline$<30$ & $751(72,77)$ & $281(27,23$ & 1 & \\
\hline $30-60$ & $372(78,48$ & $102(21,52)$ & $1,078(1,016-1,145)$ & 0,018 \\
\hline$>60$ & $78(87,64)$ & $11(12,36)$ & $1,204(1,105-1,313)$ & 0,002 \\
\hline
\end{tabular}


Pada uji Spearman's Rank Correlation didapatkan bahwa usia ibu, dan usia kehamilan, tidak memiliki hubungan kemaknaan terhadap robekan perineum. Terdapat kemaknaan pada hubungan paritas dengan robekan perineum (nilai $\mathrm{p}=0,000)$, dengan korelasi negatif $(0,186)$. Koefisien korelasi negatif menunjukkan bila paritas makin kecil, maka kejadian robekan perineum akan meningkat. Pada penelitian ini didapatkan data robekan perineum terjadi pada $85,05 \%$ primipara, dibandingkan $68,73 \%$ multipara.

Terdapat kemaknaan pada hubungan antara berat badan bayi lahir kurang dari 2500 gram dengan robekan perineum $(p=0,002)$, namun $p=0,304$ untuk bayi besar (berat bayi lahir lebih atau sama dengan 4000 gram). Hal ini masih dimungkinkan terjadi dikarenakan struktur perineum yang bersifat individual, jumlah paritas, maupun lama persalinan kala II. Korelasi positif $(0,027)$ menunjukkan pada persalinan dengan berat bayi lahir makin besar, risiko robekan perineum meningkat.

Hubungan lama kala II dengan robekan perineum juga menunjukkan kemaknaan dengan nilai $p=0,018$ untuk lama kala II 30-60 menit, dan $p=0,002$ untuk lama kala II lebih dari 60 menit. Didapatkan korelasi positif $(0,061$ dan 0,092) pada kedua kemaknaan tersebut. Bila lama kala II memanjang, maka kejadian robekan perineum akan meningkat.

Tabel 4. Faktor yang berhubungan dengan robekan perineum

\begin{tabular}{lcc}
\hline Variabel & $\mathrm{p}$ & OR $(95 \% \mathrm{Cl})$ \\
\hline *Paritas & 0,000 & $2,640(2,011-3,467)$ \\
$\quad$ Primipara & & \\
$\quad$ Multipara & & \\
*Berat bayi lahir (gram) & & 1 \\
$\quad 2500-<4000$ & & $0,419(0,270-0,651)$ \\
$<2500$ & 0,000 & $1,602(0,696-3,687)$ \\
$\quad>4000$ & 0,267 & 1 \\
*Lama Kala II (menit) & & $1,044(0,795-1,371)$ \\
$\quad<30$ & 0,756 & $1,709(1,879-3,324)$ \\
$\quad 30-60$ & 0,114 &
\end{tabular}

Untuk menilai seberapa kuat pengaruh paritas dan usia ibu hamil terhadap robekan perineum, maka dilakukan uji multivariat. Uji multivariat yang digunakan adalah uji analisis regresi linear berganda karena variabel bebas lebih dari satu. Dari tabel tersebut dapat dilihat bahwa faktor yang berperan pada terjadinya robekan perineum pada persalinan vaginal dalam penelitian ini adalah paritas serta berat bayi lahir.

Pada hasil pengaruh seluruh variabel terhadap robekan perineum, didapatkan nilai korelasi (R) sebesar 0,228 dengan koefisien determinasi $\left(R^{2}\right)$ sebesar 0,052. Hal ini menunjukkan bahwa pengaruh usia ibu, paritas, usia kehamilan, berat lahir bayi, dan lama kala II, terhadap robekan perineum adalah sebesar $5,2 \%$. Didapatkan juga nilai $F$ hitung sebesar 12,758 dengan nilai signifikansi sebesar 0,000 yang artinya bahwa model regresi dapat dipakai untuk memprediksi pengaruh berbagai variabel tersebut terhadap terjadinya robekan perineum pada persalinan vaginal. 


\section{KESIMPULAN DAN SARAN}

\section{Kesimpulan}

1. Persalinan vaginal pada usia muda (kurang dari 20 tahun) meningkatkan kejadian robekan perineum.

2. Persalinan vaginal pada primipara meningkatkan kejadian robekan perineum.

3. Berat bayi lahir yang makin besar, meningkatkan kejadian robekan perineum pada persalinan vaginal.

4. Durasi lama kala II yang memanjang, meningkatkan kejadian robekan perineum.

5. Tidak terdapat hubungan bermakna antara usia kehamilan dengan kejadian robekan perineum pada persalinan vaginal.

6. Terdapat hubungan bermakna antara paritas (faktor ibu), berat bayi lahir (faktor janin), dan lama kala II (faktor persalinan), dengan terjadinya robekan perineum pada persalinan vaginal, yang berkorelasi positif.

\section{Saran}

1. Pembatasan kehamilan dan persalinan di usia muda (kurang dari 20 tahun) maupun usia tua (lebih dari 35 tahun).

2. Deteksi risiko kehamilan dengan janin besar pada saat melakukan asuhan kehamilan.

3. Pertolongan persalinan sesuai kaidah Asuhan Persalinan Normal sehingga tidak ada keterlambatan pertolongan persalinan khususnya pada kala II.

4. Penelitian lebih lanjut hubungan keseluruhan proses kehamilan dan persalinan, sampai dengan masa nifas, terhadap kejadian robekan perineum pada persalinan vaginal.

\section{DAFTAR PUSTAKA}

1. Byrd, L.M, Hobbiss, J, Tasker, M. Is it possible to predict or prevent third degree tears? Colorectal Dis. $2005 ; 7(4): 311-8$.
2. JNPK-KR, POGI, IDAI, IBI, PPNI. Buku Acuan PELATIHAN KLINIK ASUHAN PERSALINAN NORMAL, Asuhan Esensial, Pencegahan dan Penanggulangan Segera Komplikasi Persalinan dan Bayi Baru Lahir. JNPK-KR Depkes RI; 2008. 37-94 p. (Revisi 5).

3. Kemenkes, HOGSI, POGI, WHO, IDI, IBI. BUKU SAKU PELAYANAN KESEHATAN IBU DI FASILITAS KESEHATAN DASAR DAN RUJUKAN, PEDOMAN BAGI TENAGA KESEHATAN. 1st ed. Kementrian Kesehatan Republik Indonesia; 2013. 36-49 p.

4. Fitzpatrick M, O'Herlihy C. Postpartum care of the perineum. Obstet Gynaecol. 2007 Jul;9(3):164-70.

5. Power D, Fitzpatrick M. Obstetric anal sphincter injury: how to avoid, how to repair: a literature review. J Fam Pract. 2006;55(3):193-201.

6. Williams A, Adams EJ, Tincello DG, Alfirevic Z, Walkinshaw SA, Richmond DH. How to repair an anal sphincter injury after vaginal delivery: results of a randomised controlled trial. BJOG Int J Obstet Gynaecol. 2006 Feb;113(2):201-7.

7. Fonti I, Giordano R, Cacciatore A, Romano M, La Rosa B. Post partum pelvic floor changes. J Prenat Med. 2009;3(4):57-9.

8. Kementrian Kesehatan. Ringkasan Eksekutif Data dan Informasi Kesehatan Provinsi DI Yogyakarta. Pusat Data dan Informasi Kementrian Kesehatan Indonesia; 2016.

9. Chigbu B, Onwere S, Aluka C, Kamanu C, Adibe E. Factors influencing the use of episiotomy during vaginal delivery in South Eastern Nigeria. East Afr Med J. 2008;85(5):240-243.

10. Fernando RJ, Sultan AH, Kettle C, Thakar R, Radley S. Methods of repair for obstetric anal sphincter injury. Cochrane Libr. 2006.

11. Williams A. Third-degree perineal tears: risk factors and outcome after primary repair. J Obstet Gynaecol. 2003;23(6).

12. Bozkurt M, Yumru AE, Şahin L. Pelvic floor dysfunction, and effects of pregnancy and mode of delivery on pelvic floor. Taiwan J Obstet Gynecol. 2014 Dec;53(4):452-8. 